\title{
INSTRUMENTY MUZYCZNE W KSIĘDZE JEREMIASZA
}

Okres działalności proroka Jeremiasza, pochodzącego z rodziny kapłańskiej osiadłej w Anatot, obejmujący lata ok. 626-586 przed Chr., przypada na czasy rządów w państwie judzkim pięciu władców: Jozjasza, Joachaza, Jojakima, Jojakina, Sedecjasza. Zbiega się on z dramatycznymi wydarzeniami na Bliskim Wschodzie - upadkiem imperium asyryjskiego (zdobycie Aszur w 614 r. i Niniwy w 612 r. przed Chr.), i w samej Judzie - wtargnięciem do Jerozolimy w 597 r. przed Chr. wojsk Nabuchodonozora II, ostatecznym upadkiem Jerozolimy dziesięć lat później i kolejnymi wysiedleniami ludności do Babilonii (586 i 582 r. przed Chr.), która podporządkowała sobie ościenne narody. ${ }^{1}$ Jeremiasz otrzymał prorockie powołanie w trzynastym roku panowania reformatorskiego króla Jozjasza ( Jr 1,2-19), który poniósł śmierć pod Megiddo w 609 r. przed Chr., w starciu z wojskami faraona Necho II podążającymi na północ, by wesprzeć Asyrię w walce z Chaldejczykami (2Km 35,20-24). ${ }^{2}$ Kres misji Jeremiasza w Jerozolimie - prorok piętnuje idolatrię, synkretyzm, grzechy natury etycz-

\footnotetext{
1 Stolica królestwa Izraela - Samaria - została zdobyta w 722 r. przed Chr. przez asyryjskie wojska Salmanassara V. Szerzej na temat poruszonych wyżej zagadnień historycznych zob. J. M. M i 11 e r, J. H. H a y e s, A History of Ancient Israel and Judah, Louisville, KY 1986, s. 314-436; J. B r i g h t, Historia Izraela, thum. J. R a d o ż y c k i, Warszawa 1994, s. 277-385; G. R o u x, Mezopotamia, tłum. B. Kow a lska, J. Kozłows ka, Warszawa 1998 (repr. 2006), s. 241-327; M. C o g a n, Into Exile. From the Assyrian Conquest of Israel to the Fall of Babylon, w: $\mathrm{t}$ e $\mathrm{n} \dot{\mathrm{z}} \mathrm{e}$ (red.), The Oxford History of the Biblical World, New York 2001, s. 242-275; S. H. H o r n, R K. M c C a r t e r Jr, Podzielona monarchia. Królestwa Judy i Izraela, w: H. S h a $\mathrm{n}$ k s (red.), Starożytny Izrael. Od Abrahama do zburzenian światyni jerozolimskiej przez Rzymian, thum. W. Ch ros tow sk i, Warszawa 2007, s. 191-296; J. D. P u r v i s, E. M. M e y e r s, Wygnanie i powrót. Od zburzenia Jerozolimy przez Babilończyków do odbudowy państwa żydowkiego, w: tamże, s. 297-335; F. J o a $\eta \mathrm{n}$ e s, Historia Mezopotamii w I. tysiącleciu przed Chrystusem, thum. S. Z a w a d z k i, Poznań 2007; B. E. K e 11 e, Ancient Israel at War 853-586 BC, Oxford 2007; M. V a n D e M i e roo p, Historia starożytnego Bliskiego Wschodu (ok. 3000-323 p.n.e.), thum. M. K o m o r o w s k a, Kraków 2008, s. 235-291.
}

Według 2Krn 35,25 Jeremiasz jest autorem trenu o Jozjaszu wykonywanego przez śpiewaków i śpiewaczki. 


\section{GRZEGORZ KUBIES}

nej/moralnej, choć zarazem podkreśla znaczenie nowego przymierza z Bogiem - wyznacza moment zabójstwa gubernatora Judei Godoliasza mianowanego na to stanowisko przez Babilończyków (Jr 40,7 -41,18). Po tym wydarzeniu członkowie rządu Godoliasza schronili się w Egipcie, zabierając ze sobą proroka (Jr 42,1 - 43,7), który zmarł nie wiadomo gdzie i kiedy.

W Księdze Jeremiasza daje się wyróżnić cztery części: 1. wyrocznie przeciw Judzie i Jerozolimie (Jr 1,1 - 25,38), 2. opowiadania biograficzne (Jr 26,1 - 29,32; 34,1-45,5), 3. wyrocznie nadziei ( Jr 30,1 - 33,26), 4. wyrocznie przeciw narodom obcym $(46,1$ - 51,64). Księgę Jeremiasza kończy rozdział ukazujący spełnienie się gróźb proroka i perspektywę nadziei (Jr 52,1-34). Informacje na temat powstania pierwszego zwoju mów (gróźb), datowanego na 605/604 r. przed Chr., zawiera sama Księga Jeremiasza (Jr 36,2-4), z której dowiadujemy się też, że został on zniszczony przez króla Jojakima (Jr 36,29), a następnie sporządzony na nowo $\mathrm{z}$ dodatkami, podobnie jak zapis pierwotny przez Barucha, sekretarza Jeremiasza (Jr 36,28-32). Od drugiej dekady XX w. powszechnie przyjmuje się istnienie trzech źródeł Księgi Jeremiasza oznaczanych literami: A (partie mające formę poetycką), B (fragmenty biograficzne), C (partie w formie prozaicznej). Jej kompozycja jest wynikiem prac redakcyjnych prowadzonych w różnych środowiskach, trwających do III/II w. przed Chr. Tekst Septuaginty jest o jedną ósmą krótszy od tekstu masoreckiego, dlatego powstała hipoteza o podwójnej (krótszej i dłuższej) recenzji niezachowanego oryginału. Ważny głos w dyskusji filologicznej stanowią fragmenty Księgi Jeremiasza, także wykazujące cechy dwóch recenzji, znalezione w grotach 2 (2Q13) i 4 (4QJer-a,b,c,d,e) w Chirbet Qumran. ${ }^{3}$

$3 \mathrm{Na}$ temat osoby proroka Jeremiasza i problematyki egzegetycznej księgi noszącej jego imię zob. J. A. T h o $\mathrm{m} \mathrm{p} \mathrm{s} \mathrm{o} \mathrm{n}$, The Book of Jeremiah, The New International Commentary on the Old Testament, Grand Rapids, MI 1980, s. 3-136; W. B r u e g g e m a n n, J A Commentary on Jeremiah. Exile and Homecoming, Grand Rapids, MI 1998; J. R. L u n d b o m, Jeremiah 1-20, The Anchor Yale Bible Commentaries, New York 1999, s. 55-218; W. H. S c h m i d t, Das Buch Jeremia. Kapitel 1-20, Das Alte Testament Deutsch, Göttingen 2008, s. 1-41; zob. też R. B. C h i s h o $1 \mathrm{~m} \mathrm{Jr}$., Handbook on the prophets. Isaiah, Jeremiah, Lamentations, Ezekiel, Daniel, Minor Prophets, Grand Rapids, MI 2002 (repr. 2007), s. 153-215; D. L. P e t e r s e n, The Prophetic Literature. An Introduction, Louisville, KY 2002, s. 97-135; C. H a s s e 11 $\mathrm{B}$ u 11 o c k, An Introduction to the Old Testament Prophetic Books, Chicago 20072, s. 223-260; L. C. A 11 e n, Jeremiah, A Commentary, The Old Testament Library, Louisville, KY 2008, s. 1-18; P. L. R e d d i t t, Introduction to the Prophets, Grand Rapids, MI-Cambridge 2008, s. 109-131 ; C. J. S h a r p, Jeremiah, w: M. D. C o o g a n (red.), The Oxford Encyclopedia of the 
W Księdze Jeremiasza wzmiankowane są trzy instrumenty muzyczne, dwa aerofony i jeden membranofon, generalnie poza terminem hālîl, identyfikowane poprawnie we współczesnych przekładach Biblii Hebrajskiej; są to: ${ }^{4}$

- šôfār (רפוש) - róg (Jr 4,5.19.21; 6,1,17; 42,14; 51,27)

- tôf $($ ) - bęben obręczowy $(\mathrm{Jr} 31,4)$

- hālîl (לילח) - piszczałka stroikowa (Jr 48,36 - dwukrotnie).

Odnotujmy fakt, że instrumenty muzyczne, przywołane łącznie dziesięciokrotnie, są obecne we wszystkich częściach Księgi Jeremiasza. Ponadto m.in. Jr 9,16-21 oraz Jr 31,4.13 zawierają odniesienia odpowiednio do śpiewu i do tańca, pozostających poza obszarem rozważań merytorycznych $\mathrm{w}$ niniejszym artykule. ${ }^{5} \mathrm{Cel}$, jaki stawia sobie jego autor, to interpretacja motywów muzycznych (šôfār, tōf, hālîl) w perspektywie kulturowej uwzględniającej konteksty: historyczny, biblijny, teologiczny i archeomuzykologiczny.

Books of the Bible, t. 1, New York 2011, s. 414-432; V. H. M a 11 h e w s, The Hebrew Prophets and Their Social World. An introduction, Grand Rapids, MI 2012, s. 141-158. Z opracowań w języku polskim należy wymienić: L. S t a chow i a k, Księga Jeremiasza. Wstęp-przekład z oryginalu - komentarz, Poznań 1967; T. B rz e g o w y, Prorocy Izraela, cz. I, Tarnów 1999², s. 170-227; J. Homerski, Księga Jeremiasza. Przekład i komentarz, Częstochowa 1999; M. Gołębi e wski, Dni klęski (Księga Jeremiasza), w: J. Frankowski, T. B r z e g o w y (red.), Wielki świat starotestamentalnych proroków I, Wprowadzenie w myśl i wezwanie ksiąg biblijnych, Warszawa 2001, s. 193-216.

${ }^{4}$ K. E ilige r, W. Rudolph (red.), Biblia Hebraica Stuttgartensia, Stuttgart 19975; zob. ewentualnie tekst hebrajski na stronie Deutsche Bibelgesellschaft: http://www.bibelwissenschaft.de. Odnośnie do identyfikacji terminów muzycznych wraz $\mathrm{z}$ podstawowymi informacjami na ich temat zob. E. W e r n e r, Die Musik im alten Israel, w: C. D a h 1 h a u s (red.), Neues Handbuch der Musikwissenschaft, t. 1, Laaber 1989, s. 83-86; I. H. J o n e s, Musical Instruments, w: D. N. Fre ed ma n (red.), The Anchor Bible Dictionary, t. 4, New York 1992, s. 936-937; J. B r a u n, Biblische Musikinstrumente, w: L. F i s c h e r (red.), Die Musik in Geschichte und Gegenwart, t. 1, Kassel-Stuttgart 1994, kol.. 1513-1514, 1523-1527; H. S e i d e 1, Musik und Religion. I. Altes und Neues Testament, w: G. K r a u s e, G. M ü 11 e r (red.), Theologische Realenzyklopädie, t. 23, Berlin 1994, s. 445; B. B a y e r, Music, w: F. S k o 1 n i k, M. B e$\mathrm{r}$ e $\mathrm{n}$ b a u m (red.), Encyclopaedia Judaica, t. 14, Farmington Hills 2006 ${ }^{2}$, s. 641-642. Terminy muzyczne otrzymały w Septuagincie (III/II w. przed Chr.) i Wulgacie (382-406 po Chr.) nastę-

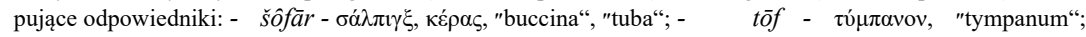
hālîl - $\alpha \nu \lambda o ́ \varsigma$, "tibia“. Oba przekłady są dostępne na: http://www.bibelwissenschaft.de.

${ }^{5}$ Zob. A. S e n d r e y, Music in Ancient Israel, New York 1969, s. 159-260 i 441-476; J. A. S $\mathrm{m}$ i t h, Music in Ancient Judaism and Early Christianity, Farnham 2011; J. L. F r i e d$\mathrm{m}$ a n n, Music in Biblical Life. The Roles of Song in Ancient Israel, Jefferson, NC 2013; t e n$\dot{\mathrm{z}} \mathrm{e}$, Music in the Hebrew Bible. Understanding References in the Torah, Nevi 'im and Ketuvim, Jefferson, NC 2014; w trzech ostatnich pracach liczne wzmianki na temat śpiewu. 


\section{Róg šôfār}

W starożytnym Izraelu/Palestynie znano dwa instrumenty dęte sygnalizacyjne. Oprócz rogu šôfār, do dzisiaj wykorzystywanego w judaizmie, posługiwano się trąbą Hăṣoṣerā, której obszar zastosowania oraz podstawowe rodzaje formuł dźwiękowych zostały zdefiniowane w Księdze Liczb. ${ }^{6}$ Polecenie wykonania dwóch trąb kutych ze srebra otrzymał Mojżesz (Lb 10, 1-10). Poza tekstem w Księdze Ozeasza, gdzie razem występuje róg i trąba $(\mathrm{Oz} 5,8)$, we wszystkich księgach prorockich wzmiankowany jest tylko pierwszy aerofon (Iz 18,3; 27,13; 58,1; Jr 4,5.19.21; 6,1.17; 42,14; 51,27; Ez 33,3-6; Oz 5,8; 8,1; J1 2,1.15; Am 2,2; 3,6; So 1,16; Za 9,14), pełniący najczęściej funkcję wojennego instrumentu sygnalizacyjnego. ${ }^{7}$ Jego znaczenie w kulturze żydowskiej epoki starotestamentalnej wynika z kilku czynników: mocy, jaką przypisywano instrumentowi (Wj 19,13.16.19; 20,18; Joz 6,4.8-9.13.16.20; Za 9,14), właściwości akustycznych (dynamika; Iz $58,1)$ oraz $\mathrm{z}$ prostej $\mathrm{w}$ istocie technologii wykonywania owego narzędzia dźwiękowego, mimo licznych wskazówek zachowanych w literaturze talmudycznej dotyczących jego koszemości. ${ }^{8}$ Jako instrument niemelodyczny (wykonuje się na nim zazwyczaj dwa-trzy dźwięki) rzadko występuje w opisach gry zespołowej (1Km 15,28; Ps 150,3). Żyjący w I w. po Chr. rabbi Hanina ben Dosa wyjaśniał tajemnicę mocy aerofonu rozbrzmiewającego podczas teofanii $(\mathrm{Wj} 19,16.19)$ tym, że wykonano go $\mathrm{z}$ lewego rogu barana złożonego w ofierze przez Abrahama zamiast Izaaka ( $\operatorname{Rdz} 22,13)$, a był on jednym $\mathrm{z}$ dziesięciu szczególnych boskich stworzeń powołanych do życia pod konieć ostatniego dnia stwarzania świata (Pirke de Rabbi Eliezer, 31). Natomiast w Misznie (dzieło spisano w II-III w. po Chr.), najstarszej części Talmudu, zarysowano ważny z punktu widzenia symboliki

6 Zapisy nutowe sygnałów wykonywanych w środowiskach aszkenazyjskich i sefardyjskich zob. A. S e n d r e y, Music in Ancient Israel, s. 353-359.

7 Pozostałe miejsca występowania terminu šôfār w Starym Testamencie: Wj 19,16.19; 20,18; Kpi 25,9; Joz 6,4.8-9.13.16.20; Sdz 3,27; 6,34; 7,8.16.18-20.22; 1Sm 13,3; 2Sm 2,28; 6,$15 ; 15,10 ; 18,16 ; 20,1.22 ; 1$ Kri 1,34.39.41; 2Krl 9,13; IKrn 15,28; 2Krn 15,14; Ne 4,12.14; Hi 39,24-25; Ps 47,6; 81,4; 98,6; 150,3. Odnotujmy, że Iz 27,13, J1 2,1.15; So 1,16 sytuują róg šôār w kontekście eschatologicznym.

8 Podstawowe omówienie przepisów talmudycznych dotyczących rogu šôfār zob. A. S e nd r e y, Music in Ancient Israel, s. 344-352; A. L. L e w i s, Shofar, w: F. S k o 1 n i k, M. B e r e nb a u m (red.), Encyclopaedia Judaica, t. 18, s. 506-508; J. M o n t a g u, Instrumenty muzyczne Biblii, tłum. G. K u b i e s, Kraków 2006, s. 39, 155-159. 
instrumentu apotropaiczny profil rogu (Rosz ha-Szana, 16b; Taanit, $3,1-\quad 3,2 ; 3,5) .{ }^{9} \mathrm{~W}$ świecie starożytnym $\mathrm{w}$ celach sygnalizacyjnych oprócz naturalnych rogów barano w i kóz wykorzystywano też m.in. rogi antylop i bydła oraz niektóre muszle morskie, np. trytona. Sposób przygotowywania rogu do gry polegał na wyczyszczeniu pochwy rogowej za pomocą ciepłej wody lub wręcz wystawieniu jej na działanie powietrza $\mathrm{i}$ much oraz wycięciu $\mathrm{w}$ niej otworu zadęciowego. ${ }^{10}$ W celu uzyskania specyficznych właściwości brzmieniowych stosowano, jak zapewnia Arystoteles, wypiekanie (O głosach, 802b). Na podstawie przekazów piśmiennych i archeologicznych z obszaru Bliskiego Wschodu należy skonstatować, że róg ( ̌̌ôfâr i qeren [Joz 6,5; Ez 7,14]) stanowił szczególny wyróżnik kultury izraelskiej. ${ }^{11}$

W żadnej z ksiąg prorockich róg šôfār $r$ najczęściej wzmiankowany instrument w Starym Testamencie, nie jest wymaniany tak często jak w Księdze Jeremiasza. Choć lektura tej księgi niezbicie dowodzi, że prorok był uważnym obserwatorem życia, to powyższy fakt nie tłumaczy w pełni swoistej predylekcji instrumentologicznej. Próba uchwycenia jej genezy (zagadnienie to wymaga osobnego omówięnia) musi uwzględniać zarysowane na początku artykułu aspekty historyczne epoki kryzysu religijnego i politycznego, epoki naznaczonej działaniami wojennymi. Istotne w prowadzonej dyskusji są słowa, jakie Jeremiasz usłyszał $\mathrm{w}$ momencie powołania na proroka, które $\mathrm{W}$ istocie nastąpiło przed jego narodzinami (Jr 1,5): „Daję ci dzisiaj władzę nad narodami i nad królestwami, byś wyrywał i obalał, byś niszczył i burzył" (Jr 1,10). ${ }^{12}$ Przepowiadanie nieszczęść stanowiło

${ }^{9}$ Zob. M. M i 11 e r, The Shofar and its Symbolism, Historie Brass Society Journal 14/2002, s. 83-113.

${ }^{10}$ A. B a $\mathrm{i}$ n e s, Brass Instruments. Their History and Development, London 1976 (repr. New York 1993), s. 44. W procesie przygotowywania rogu wykorzystuje się też parę wodną; zob. C. S a c h s, Historia instrumentów muzycznych, thum.. S. O 1 ę d z k i, Kraków 1989², s. 91; J. M o n t a g u, Origins and Development of Musical Instruments, Lanham, MD 2007, s. 105.

11 Badania ikonograficzne rogu śófcir umożliwiają przekazy pochodzące dopiero z III-I w. przed Chr. J. B r a u n, Music in Ancient Israel/Palestine. Archeological, Written, and Comparative Sources, thum. D. W. S t o 11, Grand Rapids, MI 2002, s. 192 ; por. H. M. K ii m m e 1, W. S t a u d e r, Horn (Musikinstrument), w: D. O. E d z a r d (red.), Reallexikon der Assyriologie und vorderasiatischen Archäologie, t. 4, Berlin-New York 1972-1975, s. 469-471; E. H i c k$\mathrm{m}$ a n $\mathrm{n}$, Horn (Musikinstrument), w: W. H e l c k, W. W e s t e $\mathrm{nd}$ o r f (red.), Lexikon derÀgyp-tologie, t. 3, Wiesbaden 1980, kol. 10-11; M . D u c h e s n e - G u i 11 e m i n, Music in Ancient Mesopotamia and Egypt, World Archaeology 12 (1981) 3, s. 291.

12 Wszystkie cytaty biblijne podaję za: K. S a $\mathrm{r}$ z a I a (red.), Biblia Jerozolimska, Poznań 2006 (tekst Biblia Tysiąclecia, Poznań 20005). 
źródło wewnętrznego cierpienia do tego stopnia, że Jeremiasz przeklinał dzień swych narodzin (Jr 20,14).

Topos rogu jako narzędzia sygnalizacyjnego pojawia się kilkakrotnie $\mathrm{w}$ wyroczni o nieprzyjacielu $\mathrm{z}$ północy $(\mathrm{Jr} 4,5-31$; zob. 1, 15), który nie został tutaj dookreślony, choć jego identyfikacja w świetle treści Księgi Jeremiasza i wydarzeń historycznych z początku VI w. przed Chr. nie nastręcza trudności. Owym lwem, który „wyruszył ze swego legowiska" (Jr 4,7), był zdobywca Jerozolimy, Nabuchodonozor II. Za interwencją Babilończyków, mającą nastąpić z przyzwolęnia Boga (Jr 4,6), stały nieprawości mieszkańców Judy, a w szczególności Jerozolimy ( $\mathrm{Jr}$ 4,4.14.18.22). Alarmujące wezwanie do schronienia się $\mathrm{w}$ miastach kierowane jest do całego narodu: "Opowiadajcie w Judzie, ogłoście w Jerozolimie! Dmijcie w trąby [šôfārr] w kraju, wołajcie głośno i mówcie: Zbierzmy się i udajmy do miast warownych!" (Jr 4,5). Dramatyzm sytuacji, oprócz odwołań wybitnie militarnych (Jr 4,29), potęguje obraz zniszczeń w królestwie Judy $(\mathrm{Jr} 4,7.20) .{ }^{13} \mathrm{~W}$ obliczu ich apokaliptycznej skali (Jr 4,23-26) "zabraknie królowi odwagi, zabraknie i dostojnikom, kapłanów ogarnie osłupienie, a prorocy oniemieją" (Jr 4,9). Choć kraj ma zostać spustoszony, to nie będzie to zagłada totalna $(\mathrm{Jr} 4,27 ; 5,18)$. Rozpacz proroka nad zaistniałą sytuacją, której nie był w stanie zapobiec (Jr 4,22), wyraża sugestywnie myśl: „Wić się muszę w boleściach! Ściany mego serca! Burzy się we mnie serce - nie mogę milczeć! Usłyszałem bowiem dźwięk trąbki [šôfâr], wrzawę wojenną" (Jr 4,19). W podobnym tonie utrzymane jest pytanie retoryczne: „Dokądże mam oglądać godła wojenne i słuchać dźwięku trąb [šôfār] ?” (Jr 4,21). Róg šôfār W Jr 4,5.19.21 jawi się nie tylko jako element języka profetycznego, ale i organiczny składnik ówczesnej sonosfery.

Po refleksjach nad motywami kary (Jr 5,1-31), w których przypomniano wykonawcę woli Boga $(\mathrm{Jr} 5,15)$ i nakreślono potęgę Stwórcy wyrażającą się w Jego dominacji nad siłami natury (Jr 5,22), ponownie pojawia się temat najazdu na Jerozolimę ludu „,z krańców ziemi” (Jr 6,22), ludu słynącego z okrucieństwa (Jr 6,23). Wobec braku czci i poszanowania prawa $(\mathrm{Jr} 6,10.19)$ na nic zdają się ofiary kadzielne,

13 Rozmaite zagadnienia wojskowe, w tym problematykę miast warownyc, podejmuje R. d e V a u x, Instytucje Starego Testamentu, tłum. T. B r z e g o w y, t. 1-2, Poznań 2004, s. 229-283. $\mathrm{Na}$ temat Jerozolimy zob. G. A u 1 d, L. S t e i n e r, Jerusalem I. From the Bronze Age to the Maccabees, Cambridge-Macon, GA 1996; A. G. V a u g h n, A. E. K i 11 e b r e w (red.), Jerusalem in Bible and Archaeology. The First Temple Period, Atlanta, GA 2003. 
pokarmowe i całopalne (Jr 6,20) składane przez naród, który nie skorzystał z kolejnej szansy powrotu na właściwą drogę $(\mathrm{Jr} 4,1 ; 5,1 ; 6,8)$. Swój niechlubny udział w zagubieniu religijno-moralnym Judejczyków mieli też kapłani i oficjalni prorocy (Jr 6,13-15; zob. 5, 31). Do ucieczki z Jerozolimy zostali wezwani synowie Beniamina $(\operatorname{Jr} 6,1)$. W wyroczni zapewne nie chodzi o tę konkretną grupę etniczną, lecz o garstkę wybranych, którzy mieli zostać ocaleni z pogromu. Podobnie jak w Jr 4, 5-6 czytamy, że podczas koordynacji działań obronnych posługiwano się rogami i znakami (zazwyczaj kierowały one uciekających do ufortyfikowanych miast): „W Tekoa dmijcie w trąby [šôfār]! Na Bet-ha-Kerem wywieście znak!” (Jr 6,1). Funkcję rogu jako aerofonu sygnalizacyjnego znakomicie oddają słowa: „I ustanowiłem dla was stróżów: Uważajcie na głos trąby [šôfār ]!” (Jr 6,17).

O lokalizacji strażników nad bramami miast i w wieżach informują 2Sm 18,24 i 2Krl 9,17. Zgodnie z tekstem z Księgi Ezechiela, prorok wyposażony w róg był odpowiedzialny nie tylko za sferę świecką, ale i na wskroś duchową, powierzonych jego opiece ludzi (Ez 33,2-9).

Po zabójstwie Godoliasza, Jeremiasz nie przejawiający już wyraźnej działalności prorockiej, pytany o zdanie odradzał ucieczkę do Egiptu. Podejrzewany wręcz o sympatie filobabilońskie (Jr 43,3) zalecał zgodnie z otrzymanym słowem Boga pozostanie w Judei. Podporządkowanie się nakazowi Stwórcy miało przynieść ocalenie ,przejawiające się brakiem jakichkolwiek działań represyjnych ze strony Babilończyków - co zdaje się potwierdzać historia - a nawet pomyślność Judejczykom (Jr 42,10-22). Niewątpliwie kraj faraonów kojąrzył się ówczesnym elitom $\mathrm{z}$ pokojem i dobrobytem, dlatego pojawia się następująca uwaga: „Raczej chcemy udać się do ziemi egipskiej, gdzie nie będziemy oglądać ani wojny, ani słyszeć głosu trąby [šôfār], ani łaknąć chleba" (Jr 42,14).

Zbiór gróźb przeciw narodom obcym zamyka najdłuższa wyrocznia $\mathrm{w}$ Księdze Jeremiasza skierowana przeciw głównemu wrogowi Izraela i Judy - Babilonowi (Jr 50,1 - 51,64), który za panowania Nabuchodonozora II stanowił ważny element planu Boga ( $\operatorname{~rr~51,20-23;~}$ zob. 25,1-13; 27,6-8). ${ }^{14}$ Jednak grzech zuchwalstwa wobec „Świętego Izraela" (Jr 50,29-32) oraz odpowiedzialność za zburzenie świątyni

14 Odnotujmy, że Księga Ezechiela nie zawiera wyroczni skierowanej przeciw Babilonowi. Ezechiel, uprowadzony w 597 r. przed Chr. do Babilonii, prowadzi! działalność prorocką w kraju Chaldejczyków w latach ok. 593/592-571/570 przed Chr. Takową wyrocznię, a ponadto przeciw Asyrii, zawiera Księga Izajasza (Iz 13,121,1-10 ;14,3-27 ;22-). Babilon został zdobyty w 539 r. przed Chr. przez Persów dowodzonych przez Cyrusa II. 
jerozolimskiej (Jr 51,11), stanowią główny motyw kary na „młot całej ziemi” (Jr 50,23), „górę zagłady” (Jr 51,25). Pan Zastępów (Jr 50,34) przy pomocy ludów z północy, pośród nich Medów (Jr 50,3.9.41; 51,11.27-28), zamieni Babilon $\mathrm{w}$ pustynię (Jr 50,3.13.23.39-40), miejsce zamieszkania zwierząt stepowych, szakali i strusi ( $\operatorname{Jr} 50,39$; 51,37). ${ }^{15}$ Proroctwo otwierają dwa tematy: zdobycie stolicy imperium i pohańbienie panteonu bóstw na czele $\mathrm{z}$ Mardukiem oraz powrót $\mathrm{z}$ wygnania (Jr 50,2-5). ${ }^{16}$ Wezwanie bojowe: „Wznieście znaki w kraju! Dmijcie w trąby [šôfâr] wśród narodów! Do świętej wojny z nim przygotujcie narody!" (Jr 51, 27) i kolejne trzy wersety przypominają $\mathrm{Jr}$ 4,5-7. Określenie zmagań wojennych mianem świętej wojny (Jr 51,27-28) przywodzi z kolei na myśl opis zdobycia Jerycha (Joz 6,1-27). ${ }^{17}$ Latwo uchwytne paralele obejmują trzy elementy: Izraelici nie występowali w wojnie czynnie (Arka Przymierza [Bóg] i wojska $\mathrm{z}$ północy [Persowie]), podczas burzenia murów miejskich wznoszono okrzyki wojenne/czyniono wrzawę (Joz 6,5.10.15.20; Jr 50,15) oraz posługiwano się aerofonami (Joz 6,4-6.8-9.13.16.20; Jr 51,27).

\section{Bęben obręczowy töf}

Bęben tōf jest wymieniany w Biblii jako instrument solowy, którym - tutaj objawia się charakterystyczny rys kulturowy instrumentu - posługiwały się kobiety podczas akompaniamentu do tańca, m.in. Miriam (Wj 15,20) i córka Jeftego (Sdz 11,34). Łączono go także z lirami [kînnôr, nèvell i piszczałkami [hālîl, 'র̂gāv] (1Sm 10,5; Hi 21,12; Iz 5,12), ponadto z talerzami [șelșélîm] i grzechotkami ['aș̣ey berōšîm] (2Sm 6,5), a nawet $\mathrm{z}$ trąbami [hăṣoṣerā] (1Krn 13,8). Gra na bębnie oraz na lirach towarzyszyła śpiewakom (Ps 68,26; 81,3; 149,3). Mem-

${ }^{15} \mathrm{~W}$ Jr 50,18 adresatem gniewu Bożego jest także król asyryjski.

${ }^{16}$ Zob. Jr 50,27; 51,17-18.44-47.52 (religia), Jr 50,19 (wygnanie).

${ }^{17}$ Zob. M. L i n d, Yahweh is a Warrior. The Theology of Warfare in Ancient Israel, Scottdale, PA 1980; S.-M. K a n g, Divine War in the Old Testament and in the Ancient Near East, Berlin 1989; M. W a $1 \mathrm{z}$ e r, The Idea of Holy War in Ancient Israel, Journal of Religious Ethics 20(1992) 2, s. 215-228; T. L o n g m a n III, D. G. R e i d, God is a Warrior, Grand Rapids, MI 1995; R. S c h m i t t, Der "Heilige Krieg" im Pentateuch und im deuteronomistischen Geschichtswerk. Studien zur Forschungs-, Rezeptions- und Religionsgeschichte von Krieg und Bann im Alten Testament, Münster 2011; S. B. C h a m p m a n, Martial Memory, Peaceable Vision. Divine War in the Old Testament, w : H. A. T h o m a s, J. Eva n s, P. $\mathrm{C}$ o p a n (red.), Holy War in the Bible Christian Morality and an Old Testament Problem, Downers Grove 2013, s. 47-67; zob. też klasyczną pozycję: G. v o n R a d, Der Heilige Krieg im alten Israel, Zürich 1951. 
branofon ten nie pojawia się w Starym Testamencie w kontekście sensu stricto sakralnym, tzn. nie wykorzystywano go w służbie świątyńnej (por. 1Krn 16,4-7; 25,1). Radość muzykowania na bębnie przenika $\mathrm{w}$ niemal równym stopniu sferę kultyczną (Psalmy) i świecką (Rdz 31,27; Hi 21,12). W księgach prorockich instrument wzmiankowany jest pięciokrotnie: Iz 5,12; 24,8; 30,32; Jr 31,4; Ez 28,13. ${ }^{18}$ Bęben tōf pozbawiony najprawdopodobniej elementów brzęczących, w jakie wyposażone są współczesne tamburyny, składał się z drewnianej obręczy mającej formę koła (być może też kwadratu) oraz z jednej lub dwóch membran. ${ }^{19}$ Kinnim 3.6, traktat z Miszny, informuje, że do wyrobu membrany używano baraniej skóry. Najwcześniejsze przekazy ikonograficzne na jego temat pochodzące ze starożytnego Izraela/Palestyny są datowane na lata 1900-1600 przed Chr. (rysunki z pustynnej wyżyny Negew). ${ }^{20} \mathrm{Z}$ epoki żelaza (1200-586 r. przed Chr.) zachowały się liczne terakotowe figurki i plakietki przedstawiające kobiety $\mathrm{z}$ bębnem (m.in. Jerozolima, Israel Antiquities Authority [44.54; 81.246; 84.62]; Amman, Jordan Archaeological Museum [J.7285]). ${ }^{21}$ Rozmaite membranofony, w tym odmiany bębna obręczowego, znano w Mezopotamii i Egipcie, gdzie - podobnie jak w Izraelu - stanowił charakterystyczny atrybut muzykujących kobiet. ${ }^{22}$

18 Pozostałe miejsca występowania terminu tōf w Starym Testamencie: Rdz 31,27; Wj 15,20; Sdz 11,34; $1 \mathrm{Sm} 10,5 ; 18,6 ; 2 \mathrm{Sm} 6,5 ; 1 \mathrm{Krn} \mathrm{13,8;} \mathrm{Hi} \mathrm{21,12;} \mathrm{Ps} \mathrm{68,26;} \mathrm{81,3;} \mathrm{149,3;} \mathrm{150,4.}$

19 Curt Sachs uważał, że bęben mógł mieć dwie membrany; t e n że, Historia instrumeritów muzycznych, s. 90. Jeremy M o n t a g przypuszcza, że bęben mógł być wyposażony w elementy brzęczące/ grzechoczące - żelazne pierścienie mocowane do obręczy czy struny rezonujące pod membraną; t e nż e, Instrumenty muzyczne Biblii, s. 36; zob. też A. S e n d r e y, Music in Ancient Israel, s. 372-375.

${ }^{20} \mathrm{~J} . \mathrm{B} \mathrm{r}$ a u n, Music in Ancient Israel/Palestine. Archeological, Written, and Comparative Sources, il. III.1.a-III.1.c, s. 73-74; tabela 1, s. XXIX-XXXI; zob. też S. P a z, Drums, Women and Goddesses. Drumming and Gender in Iron Age II Israel, Fribourg-Göttingen 2007. Wprowadzenie do archeologii muzycznej na starożytnym Bliskim Wschodzie zob. J. B r a u n, Musical instruments, w: E. M. M e y e r s (red.), The Oxford Encyclopedia of Archaeology in the Near East, t. 4, New York-Oxford 1997, s. 70-79.

21 T e nże, Music in Ancient Israel/Palestine. Archeological, Written, and Comparative Sources, il. IV.1-IV.12, s. 120-132. Zwięzłą charakterystykę kultury muzycznej w Izraelu i Judzie w epoce żelaza zawiera hasło encyklopedyczne: t e nż e, Jewish Music (II. Ancient Israel) Palestine), w: S. S a d i e (red.), The New Grove Dictionaiy of Music and Musicians, t. 13, London 2001, s. 32-34.

22 Zob. M. Duchesne-Guillemin, Music in Ancient Mesopotamia and Egypt, s. 290; E. H i c k m a n n, Trommel, w: W. H e 1 c k, W. W e s t e n d o r f (red.), Lexikon der Ägyptologie, t. 6, Wiesbaden 1986, kol. 767-769; V. D o u ble day, The Frame Drum in the Middle East. Women, Musical Instruments and Power, Ethnomusicology 43(1999) 1, s. 105-107; A. D. K i 1 m e r, Pauke und Trommel, w: D. O. E d z a r d, M. P. S t r e c k (red.), Realle- 
W Księdze Pocieszenia (Jr 30,1 - 31,40), zawierającej mowy dotyczące odmiany losu dotkliwie doświadczanych Izraela i Judy, wcześniejszemu obrazowi piętnowanej Dziewicy-Izraela $(\mathrm{Jr} 18,13)$ przeciwstawiany jest obraz zgoła odmienny $(\mathrm{Jr} 31,4) .{ }^{23}$ Wyrazem nowego przymierza z oboma królestwami (Jr 31,31-34), budowanego na fundamencie duchowej przemiany (Jr 31,33), ma być powrót do ziemi przodków, perspektywa dostatniego życia, pomnożenie ludzi i zwierząt. Bóg tym razem, będzie „budować i sadzić” (Jr 31,28). Jednym $\mathrm{z}$ przejawów zapowiadanych przemian ma być uzewnętrzniona radość: „Znowu cię zbuduję i będziesz odbudowana, Dziewico-Izraelu! Przyozdobisz się znów swymi bębenkami [tōf] i zaczniesz tańce pelne wesela" (Jr 31,4). ${ }^{24}$ Powyższy opis dopełniają dwa stychy: „Wtedy ogarnie dziewicę radość wśród tańca, i młodzieńcy cieszyć się będą ze starcami" (Jr 31,13). Przez obecność motywów bębna i tańca Jr 31,4 wykazuje związki z realną praktyką muzyczną na Bliskim Wschodzie. Za sprawą motywu muzykującej dziewicy objawiają się $\mathrm{w}$ nim treści symboliczne, łączone $\mathrm{z}$ subtelnym erotyzmem i płodnością. ${ }^{25}$ Kluczową rolę $\mathrm{w}$ powyższej egzegezie odgrywa perykopa o złożonym ślubie Jeftego i opłakiwaniu dziewictwa jego córki (Sdz 11,29-40), która „wyszła na spotkanie, tańcząc przy dźwiękach bębenków [tōf]” (Sdz 11,34), by zostać następnie złożoną w ofierze całopalnej (Sdz 11,32.35). ${ }^{26}$ Nie bez znaczenia pozostaje fakt, że niektóre artefakty z epoki żelaza przedstawiają postaci nagich lub półnagich kobiet $\mathrm{z}$ bębnem obręczowym.

xikon der Assyriologie und Vorderasiatischen Archäologie, t. 10, Berlin-New York 2003-2005, s. 367-371 ; zob. też J. B 1 a d e s, Percussion Instruments and Their History, London 1992 (repr. 2005), s. $152-160$.

23 Zwróćmy uwagę, że hebrajskie rzeczowniki - 'almâ i bětûlâ thumaczone jako "dziewica" w Starym Testamencie nigdy nie odnoszą się do bogiń. W tekstach ugaryckich tym mianem określana jest kananejska bogini Anat, siostra i kochanka Baala; P. L. D a y, Anat, w: K. v a n d e r To o rn, B. B e cking, P. W. van de r Horst (red.), Dictionary of Deities and Demons in the Bible, Leiden 19992 , s. 36-43; zob. też M. D. C o o g a n, M. S. S m i t h, Stories from Ancient Canaan, Louisville, KY 2012², passim. Antropomorficzne obrazy Izraela oprócz Jr 18,13 i 31,4 zawierają także inne fragmenty Księgi Jeremiasza, m.in. Jr 2,20 (nierządnica), Jr 3,3 (niewiasta cudzołożna); Jr 3,7 (niegodziwa siostra Izraela); Jr 4,31; 6,23 (Córa Syjonu), Jr 8,11.19; 9,6 (Córa mojego ludu).

${ }^{24}$ Odnośnie do Jr 31,4, Amnon S h i 1 o a h wysuwa hipotezę, że instrument o dwóch membranach mógł być wieszany na szyi grającej osoby; t e n że, Jewish Musical Traditions, Detroit, MI 1992, s. 4L

${ }^{25} \mathrm{Na}$ ten aspekt zwraca uwage J. B $\mathrm{r}$ a u n, Music in Ancient Israel/Palestine. Archeological, Written, and Comparative Sources, s. 30-31.

${ }^{26}$ Zob. komentarz do Sdz 11,34 w: T. W. B u r g h, Listening to the Artifacts. Music Culture in Ancient Palestine, New York 2006, s. 94-95. 


\section{Piszczałka stroikowa hālîl}

Piszczałka hālîl wzmiankowana jest w Starym Testamencie zaled-

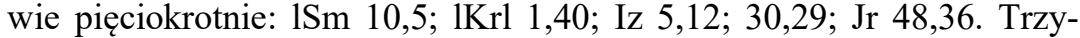
krotnie pojawia się w świeckim milieu (1Krl 1,40; Iz 5,12; Jr 48,36). W Księdze Izajasza można ją łączyć z radością obchodzenia Święta Namiotów bądź Paschy (Iz 30,29). ${ }^{27}$ W Pierwszej Księdze Samuela ukazano obraz profetycznego uniesienia, w którym aerofon ten wchodzi w skład większego zespołu obejmującego oprócz piszczałek, liry [kînnôr, $n \bar{e} v e l]$ i bębny [tōf] (1Sm 10,5); identyczny skład występuje w Iz 5,12. Jako instrument solowy piszczałka hālil wzmiankowana jest w tekstach biblijnych dwukrotnie (Iz 30,29; Jr 48,36). Instrument, składający się najprawdopodobniej $\mathrm{z}$ dwóch piszczałek (w układzie rozbieżnym lub równoległym) o przekroju cylindrycznym, wyposażonych w podwójne lub pojedyncze stroiki, budowano $\mathrm{z}$ trzciny, a zgodnie ze świadectwem traktatów wchodzących w skład Miszny także z brązu, miedzi (Arachin 2.3; Kelim 11.6) i kości (Kelim 3.6). ${ }^{28}$ Najstarsze przedstawienie instrumentu o dwóch piszczałkach ustawionych rozbieżnie, podobnie jak grecki aulos, znalezione w Tell el-Far'a jest datowane jest na połowę XIV w. przed Chr. (tabliczka z kości słoniowej; Jerozolima, Israel Antiquities Authority [33.2537]). ${ }^{29} \mathrm{Z}$ epoki żelaza, $\mathrm{z}$ terenów starożytnego Izraela/Palestyny zachowały się figurki oraz plakietki wykonane z terakoty, ceramiki i brązu przedstawiające muzykujące postaci na aerofonach podwójnych (m.in. Jerozolima, Israel Antiquities Authority $[44.56 ; 94.3394]) .{ }^{30}$ Zarówno piszczałki stroikowe jak i wargowe znano i powszechnie wykorzystywano w różnych środowiskach w Mezopotamii i Egipcie. ${ }^{31}$ Uwzględniając fakt powszechności piszczałek na

27 Wykorzystywanie piszczałek w świątyni jerozolimskiej zaświadcza literatura talmudyczna (Arachin 2.3).

${ }^{28} \mathrm{Na}$ temat budowy instrumentu oraz wzmianek na jego temat w Talmudzie zob. A. S e nd r e y, Music in Ancient Israel, s. 310-317; C. S a c h s, Historia instrumentów muzycznych, s. 100-103; J. M o n t a g u, Instrumenty muzyczne Biblii, s. 63-66; zob. też A. B a i n e s, Woodwind Instruments and their History, New York 1967 (repr. 1991), s. 189-208.

29 J. B r a u n, Music in Ancient Israel/Palestine. Archeological, Written, and Comparative Sources, il. III. 15, s. 95. Odnośnie do aulosu zob. J. G. L a n d e 1 s, Muzyka starożytnej Grecji i Rzymu, tłum. M. K a z i ń s k i, Kraków 2003, s. 41-63; M. L. W e s t, Muzyka starożytnej Grecji, thum. A. M a c i e j e w s k a, M. K a z i ń s k i, Kraków 2003, s. 97-122.

${ }^{30} \mathrm{~J}$. B $\mathrm{r}$ a u n, Music in Ancient Israel/Palestine. Archeological, Written, and Comparative Sources, il. IV.13-IV.20, s. 135-143.

$31 \mathrm{Na}$ temat instrumentów stroikowych w Mezopotamii i Egipcie zob. E. H i c k m a n n, Klarinette, w: W. H e 1 e k, W. W e s t e n d o r f (red.), Lexikon der Ägyptologie, t. 3, kol. 449-451; M. D u c h e s n e - G u i 11 e m i n, Music in Ancient Mesopotamia and Egypt, s. 291; 
Bliskim Wschodzie i w obszarze Śródziemnomorza, trudno wyjaśnić skromną kwantytatywnie reprezentację hālîl w Starym Testamencie. Obraz instrumentu w Biblii ma charakter polisemiczny, ewokuje radość (Iz 5,12; 30,29) i smutek (Jr 48,36), łączony jest ze stanami ekstazy (Sm 10,5), a także grzechem (Iz 5,12).$^{32}$ Czy specyficzny profil aerofonu wyjaśnia zaistniały stan rzeczy?

Proroctwo przeciw Moabowi (Jr 48,1-47) jest drugim co do długości proroctwem przeciw narodom obcym. ${ }^{33}$ Moabici, mimo pokrewieństwa etniczno-lingwistycznego i bliskości geograficznej, byli tradycyjnymi wrogami Izraela (Pwt 23, 4). Stosunek tego ostatniego do Moabitów dobitnie oddaje wzmianka o ich protoplaście mającym wywodzić się z kazirodczego związku Lota z jedną ze swych córek (Rdz 19,37). Ponadto $\mathrm{w}$ świetle jednego świadectwa biblijnego byli wrogami militarnymi, posłusznymi Nabuchodozorowi II (2Krl 24,2). Polityka uległości wobec Asyrii i Babilonii skutecznie chroniła mieszkańców tego niewielkie państwa o znikomym znaczeniu na ówczesnej mapie Bilskiego Wschodu przed eksterminacją (Jr 48,11). Zagłada Moabu, w którym „żadne miasto nie ocaleje” (Jr 48,8), będąca karą za drwiny kierowane pod adresem Izraela i pychę (Jr 48,27.29-30), ma obejmować także politeistyczną religię z jej głównym bóstwem Kemoszem (Jr 48,7.35.46). Obraz stanu ducha narodu pozbawionego radości manifestującej się m.in. w śpiewie ( $\mathrm{Jr} 48,33)$, stanowi wprowadzenie do refleksji w pierwszej osobie: "Dlatego też nad Moabem serce moje żali się jak flet [hālîl], moje serce nad ludźmi z Kir-Cheres żali się jak flet [hālîl] gdyż całe zgromadzone dobro utrąciii" (Jr 48,36). Lamentacyjny ton nie jest wyrazem emocjonalnego zaangażowania autora/redaktora lecz zabiegiem czysto literackim, w ramach którego podjęto próbę oddania mimetycznych właściwości

E. H i c k m a n n, Oboe, w: W. H e 1 e k, W. W e s t e n d o r f (red.), Lexikon der Ägyptologie, t. 4, Wiesbaden 1982, kol. 548-549; A. D. K i 1 m e r, Musik, w: D. O. E d z a r d (red.), Reallexikon der Assyriologie und vorderasiatischen Archäologie, t. 8, Berlin-New York 1993-1997, s. 464-465; K. V o 1 k, Pfeife, w: tamże, t. 10, s. 455-456; zob. też A. B a in e s, Woodwind Instruments and Their History, New York 1967 (repr. 1991), s. 190-208.

${ }^{32}$ Rdzeń $H U$ obecny w Hālîl występuję w wyrazach „kalać”, „profanować”; F. B $\mathrm{r}$ o w $\eta$, S. R. D r i v e r, C. A. B r i g g s, A Hebrew and English Lexicon of the Old Testament, Oxford 1907 (repr. 1975), s. 320; G. J. B o t t e r w e c k, H. R i n g g r e n (red.), Theological Dictionary of the Old Testament, t. 4, Grand Rapids, MI 1980 (repr. 1997), s. 409-410.

33 Wyrocznia przeciw Moabowi w Księdze Izajasza, której reminiscencje zawiera Jr 48,1-47, liczy dwadzieścia trzy wersety (Iz 15,1-16,14). W Księdze Ezechiela brak wyroczni skierowanej przeciw temu narodowi. 
aerofonu. ${ }^{34}$ Naśladownictwo w grze instrumentalnej obejmuje żarówno aspekty artykulacyjne jak i melorytmiczne. W Księdze Izajasza w analogicznej wyroczni pojawia się lira: „Dlatego trzewia me jęczą, jak cytra [kînnôr], nad Moabem, i moje wnętrze nad Kir-Chares" (Iz 16,11). Instrumenty należące do dwóch różnych grup, jakie zostały przywołane w Jr 48,36 i Iz 16,11, zdają się dowodzić odmiennej wrażliwości audytywnej obu proroków.

\section{$* * *$}

Wystosowanie przez proroka (wkład redaktorski w Jr 50,1-51,64 jest znaczny) mowy przeciw Babilonowi stanowiło potencjalnie znakomitą sposobność do uczynienia aluzji do bogatej kultury muzycznej Mezopotamii. ${ }^{35}$ Nie podjęty przez Jeremiasza motyw muzyki instrumentalnej znalazł się w Księdze Izajasza w satyrze na obalonego króla, w której czytamy: „Do Szeolu strącony twój przepych i dźwięk twoich harf [nëvel]" (Iz 14,11). ${ }^{36}$

\section{Grzegorz KUBIES}

\footnotetext{
$34 \mathrm{Na}$ temat terminu mimesis ukształtowanego na gruncie myśli starożytnych Greków zob. W. T a ta rki e w i c z, Mimesis, w: R R W i e $\mathrm{n}$ e $\mathrm{r}$ (red.) Dictionary of the History of Ideas, t. 3, New York 1973, s. 225-230.

${ }^{35}$ Zob. F. W. G a $1 \mathrm{p}$ i n, The Music of the Sumerians and Their Immediate Successors the Babylonians and Assyrians, Cambridge 1937 (repr. 2010); H. G. F a r m e r, The Music of Ancient Mesopotamia, w: E. W e 11 e s z (red.), The New Oxford History of Music, t. 1, London 1957, s. 228-254; S. A. R a s h i d, Die Musik der Keilschriftkultur, w: C. D a h 1 h a u s (red.), Neues Handbuch der Musikwissenschaft, t. 1, s. 1-30; B. L a w e rg re n, Mesopotamien, w: L. F i s c h e r (red.), Die Musik in Geschichte und Gegenwart, t. 6, Kassel-Stuttgart 1999, kol. 133-171 ; R. D u m b r i 11, The Archaeomusicology of the Ancient Near East, Victoria, B.C. 2005; N. Z i e g 1 e r, Les musiciens et la musique d'après les archives de Mari, Paris 2007; t e $\mathrm{n} \dot{\mathrm{z}} \mathrm{e}$, Music, the Work of Professionals, w: K. R a d n e r, E. R o b s o n (red.), The Oxford Handbook of Cuneiform Culture, New York 2011, s. 288-312. Material ikonograficzny zawiera praca: S. A. R a s h i d, Mesopotamien, w: W. B a c h m a $\eta \mathrm{n}$ (red.), Musikgeschichte in Bildern, t. 2/2, Leipzig 1984. Antologię tekstów powiązanych ze Starym Testamentem zawiera praca: J. B. Pritch ard (red.), Ancient Near Eastern Texts Relating to the Old Testament, New Jersey $1969^{3}$, (repr. 1992).

36 Nēvel to, podobnie jak kînnôr "lira", najprawdopodobniej o niższym dźwięku; zob. J. B r a u n, Biblische Musikinstrumente, kol. 1516-1517, 1520-1521. Niniejszy artykuł zamyka cykl publikacji poświęconych motywom muzycznych w księgach czterech proroków „większych": G. K u b i e s, Orkiestra króla Nabuchodonozora II czy zespól Antiocha IV Epifanesa? Kilka uwag muzykologa, Ruch Biblijny i Liturgiczny 2/2005; t e n ż e, Musica non grata? Motywy i obrazy muzyczne $w$ Księdze Izajasza, Ruch Biblijny i Liturgiczny, w druku; t e n ż e, „Oto jesteś dla nich jak ten, co śpiewa o milości, ma piękny glos $i$ doskonaty instrument” (Ez 33, 32). Motywy muzyczne w Księdze Ezechiela, Collectanea Theologica 84 (2014) $\mathrm{nr} 2$.
} 